\title{
Writers and politics: Gisèle Sapiro's advances within the Bourdieusian sociology of the literary field
}

\author{
Bridget Fowler ${ }^{1}$ (D)
}

Accepted: 12 April 2021 /Published online: 21 June 2021

(C) The Author(s) 2021

\begin{abstract}
This article undertakes a critical analysis of the work of Gisèle Sapiro, with reference to sociology of literature. From 1999 (Sapiro, 2014a), Sapiro has developed the Bourdieusian research tradition, amplifying especially Bourdieu's theory of crisis. Focusing on the antagonisms between literary "prophets" and "priests", she has drawn on a rich sample of 184 writers to elucidate the struggles inherent in World War II between writers from different field positions and literary habitus. Further, her historical analyses of the ethical commitments of nineteenth century writers via a fresh microsociology of literary trials (Sapiro, 2011) has reminded us of the importance of popular poets in articulating the suffering of the subordinate classes. Her most recent book (Sapiro, 2018) has expanded on her earlier themes, whilst identifying the recuperation of certain 1930s' fascist worldviews within contemporary literature. This article notes that there is a telling divergence between Bourdieu and Sapiro on the issue of interests behind disinterestedness, exemplified in the case of Zola. On this issue, Sapiro's reading (Sapiro, 2011) is found convincing. Finally, the dialectic of avant-garde consecration and routinisation is questioned as a universal structure. It is suggested that certain avant-garde - the Harlem Renaissance, for example - did not undergo swift consecration or routinisation, although this contention deserves greater research. The paper concludes by showing that Sapiro's conception of writers' responsibility owes its origins less to Sartre than to the Durkheimian/ Bourdieusian notion of the expertise of the "specific intellectual". It welcomes Sapiro's concern for literature as a potential force for social change.
\end{abstract}

Keywords Bourdieu $\cdot$ Crises · Fascism · Heterodox intellectuals · Sapiro · Writers' professional ethics

Bridget Fowler

Bridget.Fowler@glasgow.ac.uk

1 University of Glasgow, Glasgow, Scotland, UK 
Few studies of the cultural field demonstrate the same sociological rigour and historical erudition as Gisèle Sapiro's publications. She has provided a fresh lens through which to see the impact of literature, examining in depth writers' position-takings in political convulsions such as the Dreyfus Affair, as well as in periods of revolution, defeat and national liberation. Fundamental to this is her contribution to the debate broached by Weber on prophets, secular or religious. ${ }^{1}$ In particular, she has extended Bourdieu's analysis of the epoch-making appearance of prophetic figures at times of crisis, and through this, his theory of social transformation (Bourdieu, 1985, 1987, 2013, 2016, 2019; Fowler, 2020). This article assesses the strengths and weaknesses of her approach, concluding that - despite certain omissions - she has elaborated on the sociology of literature in a manner highly fertile for later development.

In recent years, Sapiro has brought her remarkable linguistic and theoretical skills to bear on the emergent sociology of translation, ${ }^{2}$ allying her own Bourdieu-inspired perspective with the theories of centre and periphery advanced by Immanuel Wallerstein, David Harvey and Pascale Casanova (Sapiro 2008, 2009a, 2009b, 2009c, 2010 and 2015, Sapiro \& Heilbron, 2007). However, given spatial constraints, I shall focus here only on her four original monographs which offer a magisterial sociological analysis of French writers' distinctive intellectual trajectories and their literary responsibilities (Sapiro, 2011, 2014a [1999], 2014b, 2018). I shall provide, first, an exposition of her major themes, then, secondly, offer an analytical assessment of her advances within the field.

In contrast to idealist approaches to literary consecration, Sapiro's sociology of literature and translation conceives of writing as a terrain marked by historical struggles over who should be published, which works should be published and what ought never to be published. Moreover, each of her major works is underpinned by highly contested questions about the professional ethic of writers. Against the grain of recent aestheticized discourse centring on taste - and more particularly "the aptitude for [...] deciphering specific stylistic characteristics" (Bourdieu, 1984: 50) - she shows the political and ethical consequences of apparently innocent artistic choices. ${ }^{3}$ Indeed, although indebted to that of her doctoral supervisor, Pierre Bourdieu, Sapiro's sociology of literature has also taken an autonomous direction, being particularly concerned with writers' disinterested acts. Pivotal here has been the analysis of social fields. Theorised first by Marx (see Bourdieu, 2015:549), the concept of field was explored

\footnotetext{
${ }^{1}$ See especially Weber, 1948 [1919]: 77-129, 1952: chs. 11, 12 and 376-80, 1978: 439-451, and 2012 [1919] 346-53. See also Deutscher (1954).

${ }^{2}$ Sapiro has contributed greatly - along with Pascale Casanova, Johan Heilbron, and Esperança Bielsa - to producing a flourishing new subfield in this area (Bielsa, 2014, 2016; Casanova, 2004; Sapiro \& Heilbron, 2007).

${ }^{3}$ On the anti-ethical turn to aestheticization in late modernity, see Bourdieu's Distinction (Bourdieu, 1984). The latter work has been misunderstood as solely about the strategic logic of cultural distinction as a status pursuit, neglecting use-values or "internal goods" (Sayer, 1999: 409, 420). My view is that the subtext to Distinction's first chapter relates precisely to "internal goods": Bourdieu's distinction between form ("aesthetic attitude") vs function (the "popular aesthetic") echoes Schiller's (1994 [1794]) critical indictment of a society where personalities are split into two different types - the speculative/analytical spirit, appreciative only of form, as against the sensuous and moral spirit of the uneducated, limited by concern for function (cf Fowler, 1991).
} 
extensively in Weber's works (Weber, 1948; Weber, 2012), before its well-known elaboration by Bourdieu. In this article I propose to evaluate the contribution of Sapiro's major works to the Bourdieusian research tradition, both in terms of historical sociology and theoretical analyses (Sapiro, 2014b). I summarise briefly her critical assessments of the contemporary literary field, including the emergence of neofascist publishing. Given the execution and imprisonment of French collaborationist writers after the Second World War, Sapiro reminds us once again how fateful the act of writing can be.

\section{Capitals, field and literary habitus: World war II in France}

Sapiro's first book (Sapiro, 2014a [1999]) is, in my view, nothing short of a masterpiece, exploring the detailed linkages between "politics and letters" whilst avoiding any simplistic reduction to economic class alone. Her historical studies of the years from 1940 to 1953 show how the Nazi Occupation of Northern France (1940), the collaborationist Vichy Regime (1940-1945) and the subsequent Civil War of French vs French affected writers in different ways. This impact was greater from 11 th November 1942, when the Nazis also occupied the Vichy-controlled Southern Zone, although, as early as Spring 1942, the Final Solution meant that French - as well as foreign - Jews were systematically rounded up for the death camps. ${ }^{4}$ Moreover, even the stakes for literature itself were unparalleled: as James Steel reminds us, Hitler aimed to destroy French culture (Steel, 1991: 117, fn.1).

Unlike earlier histories of French literature in the Second World War, such as Steel's masterly Littératures de l'Ombre (1991), Sapiro seeks to shed light on writers' literary habitus, the socially-constructed prism through which their lived experience was "refracted" (Bourdieu, 2015: 487). It is this crucial importance of literary institutions that Bourdieu had rightly criticized as missing in certain theories that "short-circuit" the relationships between authors' social class and literary ideas (Bourdieu, 1993: 56-7, 162-3, 180-1). For both Bourdieu and Sapiro, writers' precise literary habitus are indeed partly derived from their earlier class, gender and educational experiences, but partly also from the artistic perspectives that prevail within the various institutions of the literary field. Moreover, their literary habitus determines not just positions and position-taking - such as entry into a poetic avant-garde - but propels them towards far-reaching commitments, such as literary collaboration or the Resistance, which may alter over time. The outcomes had a reverberating impact on the propaganda war:

\footnotetext{
${ }^{4}$ The Vichy statutes that legitimated antisemitism throughout France, such as the dispossession of Jewish business-owners in July 1941, served to undermine public opposition to later Nazi and Vichy deportations. Even Pétain's so-called Southern "free" zone resulted in the stripping of nationality from 15,154 citizens, the imprisonment, and often torture, of more than 130,000 political opponents and the deportation of 76,000 Jews. Throughout France, malnutrition and neglect led to the deaths of 40,000 mental hospital patients (Steel, 1991, Baert, 2015: 3, Wikipedia).
} 
Having failed to attract André Gide, the collaborators [authors who supported the Nazi diktats] flaunted Louis-Ferdinand Céline, Henri de Montherlant, and Jacques Chardonne. The homegrown (especially Communist) Resistance retorted with Louis Aragon, Paul Éluard, François Mauriac, and Jean Paulhan. [...] The Vichyists had their own stars, from Henri Pourrat to Charles Maurras, through Henri Massis. [...] each camp thus claimed literary legitimacy in this ideological war.... (2014a:1).

Sapiro explores the different cultural logics of the actors inhabiting these various literary worlds, differentiating, first, the State logic ("temporal logic") epitomised in the Académie Française, second, the media logic - or "logic of scandal" - most idealtypically displayed in the Académie Goncourt, third, the logic of aesthetic distinction or "art for art's sake" - associated quintessentially with the pre-War Nouvelle Revue Française ( $L a N R F$ ) and fourth, the avant-garde political logic - or logic of subversion - most marked in the Resistance Comité Nationale des Écrivains (National Writers' Committee (CNE)) (Sapiro, 2014a:187-9). Her sample (numbering 185) is of all those writers born 1850-1918 and active between 1940 and 1944, who were members or contributors to the institutions above and who attained sufficient visibility to enter into literary history (Sapiro, 2014a:551-553). Their biographical information was analysed particularly in the light of their social class origins, cultural "capital" (educational qualifications), gender, religion, politics and geographical provenance: social properties that determine their elective affinity for certain positions in the literary world (Sapiro, 2014a: 553-60).

Her presentation of the key determinants of writers' position-takings is represented graphically through a multiple correspondence analysis (Sapiro, 2014a: 67,- 68; cf.

Table 1 The French literary field, World War II

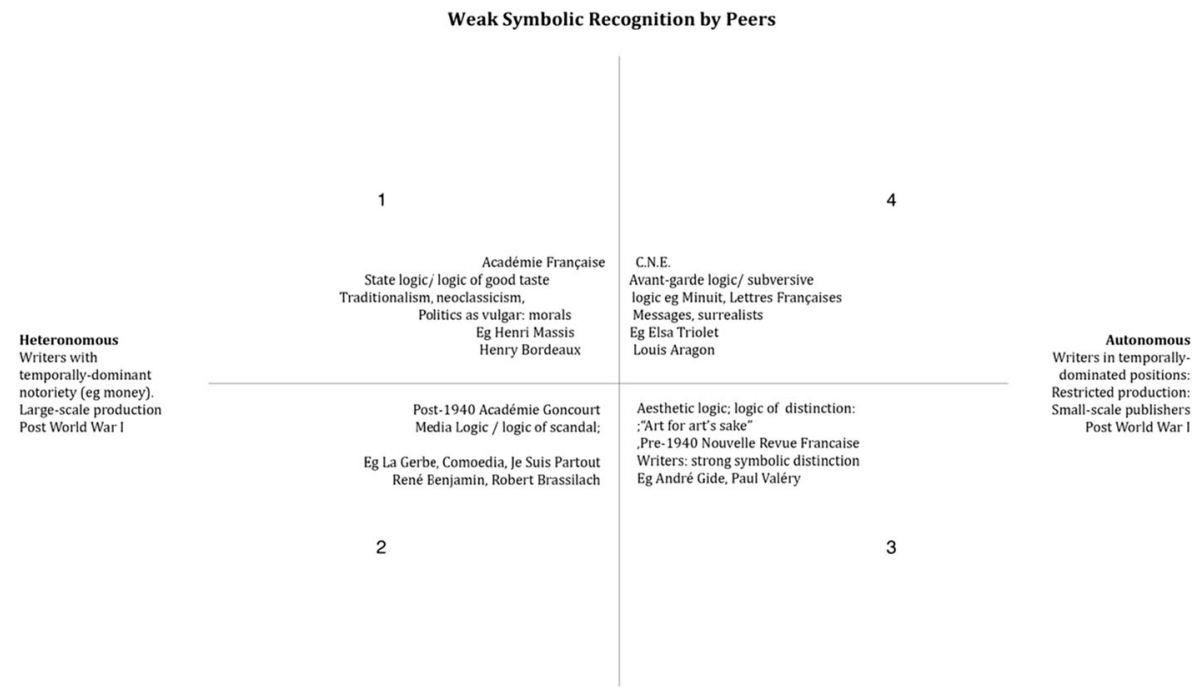


Bourdieu, 1984, 1993, 1996a). ${ }^{5}$ Writers' different positions within the literary field are gauged on the vertical axis, in terms of their institutional literary renown (1.e., "weak symbolic (literary) capital” (top, (Quadrant 1), yet Academie Française status and high sales) versus "high symbolic (literary) capital" (bottom, (Quadrant 3), aesthetic/ recognition by literary peers). Further, they are assessed on the horizontal axis according to their position on the heteronomous (left) or autonomous (right) poles; in other words, on the heteronomous left, (Quadrant 2), the nature and volume of their temporally-dominant capital (1.e. material/political resources) versus on the autonomous right (Quadrant 4), a temporally-dominated position (lack of material/ State resources). Such structural determinants - money, political power, education, or their absence - are correlated with writers' unconscious constraints and strategies, including their deep-rooted affinities towards specific positions within literary institutions. In turn, these literary institutions - academies, circles, journals - possess their own forms of solidarity or esprit de corps.

Many of these 185 writers had a literary habitus nourished by the autonomous (or restricted) cultural field, with few temporal rewards. As Bourdieu showed initially, the sphere of literary autonomy and the accompanying ideology of "art for art's sake" is in part a reaction to the industrialisation of literature - especially following mass education - from the mid-nineteenth century on (Bourdieu, 1993, 1996a). This post-1850s restricted (or "creative") field is the most independent of market sanctions. It is structured primarily by successive modernist and avant-garde movements, some of whose members are deemed worth consecrating by their peers, critics, prize juries and educationalists (Bourdieu \& Passeron, 1990: 58-9; Sapiro, 2003a). Importantly, such a distinctively autonomous literary habitus engenders greater reflexive awareness, increasing writers" "margins of liberty" in relation to the dominant social forces (see also Bourdieu, 2000: 234, 2013: 377-8).

The French cultural field entered a state of "destructuration" after the Pétain-imposed "National Revolution" (1940), its hard-won autonomy ${ }^{6}$ severely eroded (Sapiro, 2014a: $3,7)$. The crisis in the literary field was marked by an unprecedented attack on Jewish, socialist, social democratic and homosexual authors: a wave of repression that was enforced by book-burnings, exile and death in concentration camps (Sapiro, 2014a: 2425). Faced with such "heteronomous" controls, writers' practices after the "National Revolution" sharply diverged, despite still bearing the indelible mark of their earlier field-positions. In particular, their decisions were shaped by their relationship to the three institutions or organisations that became Vichy- or Nazi-controlled: the Académie Française, the Académie Goncourt and the post-1940 La NRF (edited, after 1940, by Drieu la Rochelle). Indeed, Sapiro discovers a paradox: it is the most "patriotic" writers those most keen to laud country, family and a traditional sense of honour - who go on to publish under the auspices of the Germans, hostile to French civilization, whilst the most "refractory" writers refuse publication under their control (cf also Steel: 116, fn. 13). Thus the surrealists, Michel Leiris and Raymond Queneau, decline to write for Drieu's Nazified La NRF, despite being amongst the most marginalised writers (Sapiro, 2014a: 17).

\footnotetext{
${ }^{5}$ For easier legibility, Table I is a distilled version of Sapiro's tables (Sapiro, 2014a) on pp. 67,68, 565 and 566.

${ }^{6}$ On autonomy, see Weber, 1978: Part One II and 576-610, 1995 [1905-6 and 1917]), and Bourdieu, 1996a: 47-109.
} 
Sapiro researches in depth these field-based divergences. ${ }^{7}$ Take, first, the preeminent body for writers consecrated by the State: the Académie Française (see Table 1, Quadrant 1). Under the new Vichy regime this prestigious institution remained closely complicit with power and thus "heteronomous". Académie Française writers, such as Henry Bordeaux, had earlier published regionalist novels celebrating the values of tradition, Catholicism, patriarchy and the home (cf Muel-Dreyfus, 2001), whilst certain Académie writers, such as Charles Maurras, were leaders within the protoFascist and ultra-nationalist Action Française. Thus, they actively supported Franco in both the 1925 Rif War and the Spanish Civil War, whilst contributing to the right's virulent racism and its demonisation of "uprooted" intellectuals.

For many of those "black years", one Academician alone, François Mauriac, dared to critique Pétain's Vichy Government. He took "life and death" risks as the prophetic leader of the Resistance writers: "The first consecrated writer to enter it [the literary Resistance] he brought literary legitimacy to the underground venture" (Sapiro, 2014a:181), inveighing against what he termed the "crucifixions" of Jews, the mass deportations of workers and the abandonment of foreign refugees ${ }^{8}$ (Mauriac, 1947 [1943]: 8; Sapiro, 2014a: 181-2). ${ }^{9}$ Following the disclosure of Mauriac's Black Book authorship, the Académie Française writers excoriated him as a "traitor" to the bourgeois class (Sapiro, 2014a:181-2). It was only after the German occupation had extended to the entirety of France (November 1942) - imposing round-ups, torture, imprisonment and deportation of Jews and Resistance members - that Mauriac was eventually joined in 1944 by two further Académie Française members, Georges Duhamel and Paul Valéry, who supported the Resistance's anonymous publishing and the CNE.

\footnotetext{
${ }^{7}$ It should be noted that individuals - such as Mauriac - moved across these ideal-typical spaces (Sapiro, 2014a: 175). It might be argued that Sapiro's approach does not assess adequately individual choices such as the resort to armed struggle in the Resistance, an issue that separated former pacifists from the Communists. According to Steel, the outcome of such political dilemmas hinged both on changing historical imperatives in the struggle to save France and on writers' distinctive political philosophies (1991: 215). Yet such philosophical differences are not neglected by Sapiro. Rather - as with differences in types of fascist ethos - they are linked to social determinants of class and education. Such structural properties serve to propel a writer into a particular literary habitus and institutional space, limiting the type of philosophical/ moral clashes to which they are exposed.

${ }^{8}$ Mauriac's Le Cahier Noir (Black Book), was published by the newly-formed Éditions de Minuit in 1943, under the name of Forez. Arguing that the French bourgeoisie had created a proletariat of "millions of slaves" and then capitulated to fascism, Mauriac predicts that "the working-class, alone, in its mass, will have been faithful to the profaned France" (Mauriac, 1947:17-18, see also 55).

${ }^{9}$ Sapiro goes beyond Bourdieu's theory of the literary field to explain why Mauriac should have been the sole "heretical Academician", especially since he possessed similar provincial landowning/ professional class origins to another Academician, Henry Bordeaux. Perhaps influenced by Bourdieu's analysis of Zola (Bourdieu, 1993: 50,54), she documents that Mauriac's sense of aesthetic compromise, due to his novels' success in the commercial field, was only conquered by later publication in the pre-War $L a N R F$. But the key difference between the two writers was that Bordeaux was an orthodox Catholic whilst Mauriac was profoundly influenced by his rigorously Catholic mother and by his education at an austere, heterodox Marian Brothers' school. His mother encouraged a quasi-Calvinist discipline, fostering a critical Jansenist spirit in relation to bourgeois material interests (cf Goldmann, 1964): indeed, Mauriac experienced a religious conversion - against the bourgeois laxness of Bordeaux et al. - before his political conversion. As a prophetic figure, Mauriac agonised over the competing obligations of a worldly logic (marked by his class of origin and Académie recognition), an aesthetic logic (recognition by $L a N R F$ ) and an ascetic logic, that of the Resistance (CNE) (Sapiro, 2014a: 175-185 especially 620 fn.92).
} 
The Académie Française epitomised "French civilization" and State-guaranteed recognition (Bourdieu, 1984: xi, 73-4). The Académie Goncourt, on the other hand the second "heteronomous institution" (Table 1, Quadrant 2) - had started out in 1902 as a meritocratic "Anti-Académie", situated at the boundary of the large-scale and restricted literary production. Tellingly, given the Dreyfus Affair, its prize had been awarded in 1919 to Marcel Proust (whose mother was Jewish), for A l'ombre des jeunes filles en fleurs (Sapiro, 2014a: 268).

Yet, from the 1930s, when around 100,000 copies began to be sold for each prizewinning book, the Goncourt Academy had become much more entwined with economic capital. By 1939, its "structural mechanisms" - including its financial dependence on the press - had led to its rapid accommodation to the new regime and to antisemitism. It is notable that the jurors of the 34 second - generation Goncourt Academicians had markedly lower social and educational origins than the writers of the Académie Française. Although one out of five came from rich backgrounds, a quarter of all jurors between 1940 and 1951 were petit bourgeois, compared with one in eight of the Académie. Further, at a time of growing exam certification, the Goncourt jurors' educational qualifications were hardly illustrious. None were grande école academics or graduates (Sapiro, 2014a: 249-251). Only 25\% had completed higher education (half of them had not even embarked on it): in comparison, half of the Académie Française had been to grandes écoles and two-thirds had completed the tertiary level (Sapiro, 2014a: 198).

It is hardly surprising, then, that the Académie Goncourt spontaneously adopted the Vichy ideology: "back to the land", hostility to science, democracy and secularisation, condemnation of abortion rights and of the rights of working women (Sapiro, 2014a: 260, 274-5; cf. Muel-Dreyfus, 2001, cited by Sapiro, 2014a: 637 fn. 165). Its closeness to Marshall Pétain was apparent from his attendance at its 1941 awards (Sapiro, 2014a: 277). From 1941 to 1945, even the Goncourt's literary selections were altered, women and Jewish writers being excluded. "[T] he Goncourt Académie greatly contributed to the legitimation of those writers close to or favourable to the régime" (Sapiro, 2014a: 292).

The third major institution of the literary field, the "Nazified Nouvelle Revue Française", ${ }^{10}$ became collaborationist in 1940 (Table 1, Quadrant 3). From its establishment under André Gide in 1909, La NRF's editors, writers and publishers had represented an "aristocracy of culture" (cf Bourdieu, 1984 ch 1; Sapiro, 2014a: 206). Even more highly-educated than the writers of the Académie Française, and equally materially-privileged, the contributors and Board of the magazine under the editorship of Jean Paulhan had included distinguished writers, amongst them Dadaists and the "ethnographic surrealists" (Éluard, Aragon, Queneau et al.) (Clifford, 1981). Fatefully, when Paulhan refused to serve under Nazi superintendence, the editorship was bestowed instead on the collaborationist poet, Drieu la Rochelle, who claimed to be interested only in art, whilst evicting "a number of contributors to the old $L a N R F$, Jews and anti-fascists" (Sapiro, 2014a: 317):

[T]his argument for "art for art's sake" masked the acceptance of the Nazi yoke and played into the hands of German cultural politics that aspired to normalize the situation of occupation (Sapiro, 2014a:318; cf also Baert, 2015:62).

$\overline{10}$ The phrase is Mauriac's (1947: 9). 
This move triggered the permanent boycotting of the new La NRF by most of its wellregarded writers.

In sharp contrast, within the avant-garde, and especially in the organisation set up in 1941 for integrating the writers' resistance - the Comité National des Écrivains (CNE) (Table 1, Quadrant 4) - "little magazines" sprung up such as Poésie 40, 41, Confluences, Les Lettres Françaises and Messages. These operated secret forms of "literary contraband", deploying coded language and a metaphorical use of French history to depict the present, whilst veiling their authors' identities via pseudonyms:

Anonymity became $[\ldots]$ the paradigm of disinterest [...]. Sacrificing their name to the cause that they served, the writers were definitively reinforced in the convictions that founded their professional ethics (Sapiro, 2014a: 390-1).

The scattered forces of resistance were symbolically huddled together under the umbrella of the CNE (Sapiro, 2014a: 364-8, 403). Surprisingly, rather than the usual rule of the young challenging the old (Bourdieu, 1996a: 122-123), the wartime avant-garde, such as the surrealists, became united across three generations (Sapiro, 2014a: 328, 437-8). In this respect, Sapiro shows how deep was the cultural crisis. Given the imperatives imposed on the Resistance by the forces of oppression, the generational antagonisms usually fragmenting the different avant-gardes were eliminated (cf Simmel, 1955: 92-3, 98; Sapiro, 2014b: 70-71). Further, this movement of literary and social transgression bound together writers from a variety of political groupings: from the Communist Party and its close fellow-travellers, to non-Communist radical Jews and dissenting Protestants.

This "reverse Academy" - the CNE - spread beyond the Southern and Northern zones into Algeria and Switzerland, a move accentuated as the Nazis took over the Southern Vichy zone. But the CNE's membership was by no means a representative sample of the population. Although only half as many of its recruits were from the dominant fraction of the dominant class as in the Académie Française, the CNE members came less often from the most dispossessed strata than did the writers as a whole (22\% CNE versus $27 \%$ ). They were particularly over-represented in the intellectual or dominated fraction of the dominant class: $30 \%$ came from this as against only $9 \%$ of the Académie Française or $18.9 \%$ of the total. Further, the CNE were particularly highly-educated: as many as three-quarters had educational qualifications equal to or better than the bac, compared with only half the Goncourt juries (Sapiro, 2014a: 415-419). These social and educational backgrounds are very telling, as are the links between their field position and literary practices. They indicate that, far from membership of the Resistance amongst writers being random, it is linked to family social origins in the liberal or radical professions: the "Left Hand of the State" as Bourdieu entitled these. It is also linked to high levels of tertiary education, suggesting that the examples of autonomous cultural and social action inculcated within these contexts has an impact on their former students' later practices.

\section{The genesis of the modern literary field and literary ethics}

La Responsabilité des Ecrivains (Sapiro, 2011) offers an elaboration of Bourdieu's genetic structuralist method in The Rules of Art (Bourdieu, 1996a). In doing so, it lays 
bare the historical dynamics of literary production in capitalist modernity (Sapiro, 2011:33). It exposes the French State's frequent resort to law to deny authors' claims for autonomy, focusing on the major trials of Pierre-Jean Béranger (1780-1857), PaulLouis Courier (1772-1825), Gustave Flaubert (1921-1880) and Émile Zola (1840-1902).

At the heart of these judicial proceedings are clashing interpretations of the law regulating writers' responsibility. Sapiro's attentive reading of the trials reveals a further paradox. Whereas, in the nineteenth century, it was the political right that held writers to be subjectively responsible for the allegedly dangerous effects of their writing, at the Épuration (purge), in 1944-6, it was above all the left that insisted on writers' subjective responsibilities (Sapiro, 2011: 566-7, see also 2002a).

Sapiro complements such debates on responsibility with analyses of reception. Here she rightly emphasizes not just "doxic" or orthodox interpretation of literary works but their potential for generating oppositional readerships, or, in Stuart Hall's terms, "decoding" "against the grain" of the text (Sapiro, 2011: 454, cf. Hall, 1980: 172-3). In this respect, she usefully goes beyond Bourdieu, whose empirical studies assess taste or distaste for a specific work of art, but rarely contrapuntal readings.

La Responsabilité ....is a salutary reminder to those in the contemporary West who have forgotten the impact of Napoléon III, Boulangism (1885-1889), the Dreyfus Affair and fascism. The writers noted above, together with others alluded to more briefly - Baudelaire, Hugo, Wilde, Descaves and Rebatet - were either fined and imprisoned for long periods or forced into exile. They became more vulnerable when satirising the dominant class, particularly when laying bare institutional barbarism, as did Descaves in revealing French army officers' brutal treatment of conscripts.

Writers on trial were caught in a dilemma. They wanted to be well-known and memorable, yet for the prosecution to attribute them with talent only rendered them more responsible for any disruption (Sapiro, 2011: 113-4). Further, gaining a popular public in the July Monarchy only enhanced their objective guilt in their prosecutors' eyes. Take a poet from the subordinate classes such as Béranger, whose father was a grocer and his mother a milliner (Sapiro, 2011: 60). Held by his admirers to be the "Voltaire of the folk", "beloved of the poor", ${ }^{11}$ he was viewed by the State as dangerous since he claimed to speak for labourers and artisans, even women shop assistants (Sapiro, 2011: 67, 163). Similarly, the well-known pamphleteer, Paul-Louis Courier, was imprisoned for writing in a direct popular style, exemplifying the plebeian ethic of speaking "truth to power" (Sapiro, 2011: 160-164).

Writers' funerals also conferred an oblique acknowledgement of a controversial writer's popular esteem. This was the case, for example, with Zola, despite having faced prosecution for his defence of Dreyfus in 1898-9 (Sapiro, 2011: 495, 505-512). In gratitude for his celebrated "J'accuse...!" (L'Aurore, Jan. 13, 1898), and for his sympathetic portrayal of striking miners in Germinal, the huge crowds who mourned him at his State funeral paid homage with a murmured chorus: "Germinal, Germinal" (Sapiro, 2011: 506). Similarly, Victor Hugo had to be granted a State burial despite having been forced into exile by the censors' hostile reception to his Les Misérables (1862) and his active support for the Paris Commune (1871). In one week, between his death in 1885

\footnotetext{
${ }^{11}$ Here, as elsewhere, where Sapiro's publications are as yet only in French, the translation is by this author.
} 
and the subsequent committal of his body to the Panthéon, Hugo's writings became consecrated as part of French national literature (Sapiro, 2011: 350). Moreover, as BenAmos (2000) also demonstrates, such funerals and the ensuing State recuperation of the writer, were far from disinterested. Sapiro reveals how such acts of consecration were followed by the social construction of an "acceptable" writer for the official collective memory, including the curriculum (Sapiro, 2011:351; cf. Fowler, 2007).

It is my view that Sapiro breaks new ground in terms of Bourdieusian theory by acknowledging works that both received critical recognition for their aesthetic inventiveness and also acquired a faithful mass following. Indeed, her casestudies of Courier and Béranger show that it is precisely the popular nature of this public that is at stake in those songs and pamphlets critical of the dominant class and Church.

For Bourdieu, what we might call the tragic division of literature into the restricted and large-scale subfields of production was a consequence of the changed morphology of the literary field in the 1850s (Bourdieu, 1993; Bourdieu, 1996a). The turn towards the novel of "formalist realism" - formal experimentation as well as realism - demarcates writers such as Flaubert from those cultural producers without material support. These latter, forced to write for the newly-educated mass public, produced lucrative work which often lacked literary value (Bourdieu, 1996a: 57, 734, 93, 263-4).

Béranger and Courier - recognised by their fellow-writers as both aesthetically powerful and immensely popular - flourished in the July Monarchy (1830-48), before that fateful split in the field. For this reason, they present no direct clash with Bourdieu's argument. Nevertheless, Sapiro, by stressing their popularity, sheds light on an area that was neglected by Bourdieu himself. For these charismatic oppositional figures, so feared by the State, are also seen by Sapiro as epoch-making "prophets" of a "symbolic revolution", much as Bourdieu regarded Manet as a heretical painter (Bourdieu, 2013, Sapiro, 2003b: 638-9). Béranger, for example, after being visited in prison by Hugo and other writers, had recorded that:

'Their visits were the prize for all the struggles I had embarked on in favour of the literary revolution which they and their friends had dared to attempt and which was (...) nothing but a late consequence of the political and social revolution' (cited 2011: 89-90) (my emphasis).

Further, like Bourdieu himself, Sapiro recognises the prophetic force of Zola's widelyread "J'Accuse...!", on behalf of Dreyfus. The best-selling novelist's two subsequent trials in Paris for defamation of the military authorities ended in his exile, thus escaping a 3000 franc fine and a year's imprisonment. We shall return, below, to the theoretical implications of Zola's public interventions.

Sapiro addresses fully the post-War "Épuration" (Sapiro, 2011: 525-626, 2014a: 437-90). Here the high number of writers punished (57\% of those prosecuted), compared to collaborators in the economic sector (12\%) is particularly striking (Sapiro, 2011:522, 560, 2014a: 459). Sapiro emphasizes, convincingly, that the straightforward attribution of books to individual authors made for easier prosecutions; in contrast, attributing responsibility for corporate manslaughter in the case of industrial companies largely escaped the judicial gaze (Sapiro, 2011: 522). 
Extending her earlier research (Sapiro, 2014a), she provides further evidence about the writers' trials, showing in more detail that the 55 collaborators ("collaborationistes") ${ }^{12}$ came from specific positions in the literary field, especially from the heteronomous Académie Française (such as Charles Maurras) and the Nazi-controlled La NRF (exemplified by its editor, Drieu la Rochelle) (2002: 235).

The poet, Brasillach, and nine other writers, were sentenced to death (Sapiro, 2014a: 478, 2011:722); Drieu committed suicide, his guilt indisputable. Maurras suffered a lesser punishment (life imprisonment and dégradation nationale) (Sapiro, 2014a: 501, 2011: 636-655). Céline was fortunate to be exempted from the death sentence. Although he had republished in 1943 his pro-German, anti-Jewish Bagatelles pour un Massacre (1937), its small circulation was held to lessen his "objective" responsibility (Sapiro, 2011: 604, 25-6).

Sartre is one of the key authors to whom Sapiro dedicates the last part of the book, a central figure for Bourdieu's critique of over-voluntaristic philosophies of practice that underestimate the determinants of social action by structural forces (Bourdieu, 1980, 1990: 42-48). Focusing especially on Sartre's conception of literary commitment, she draws attention to the cleavages over punishment that emerged within the Resistance literary field. On the one hand, there were those - such as de Beauvoir and Sartre - who refused to sign the 1945 Petition asking that Brasillach's death sentence be commuted. These "intransigeants" were all from the younger generation. On the other hand, there were those requesting clemency: Mauriac, Paulhan, Camus and the belated Académie Française adherents to the CNE; Camus excepted, such "indulgents" were from the older generation (2002: 236, 2011, 2014a).

\section{The role of writers in resistance and transformation: Fascism and neo-fascist populism}

Perhaps the greatest achievement of Sapiro's latest book, Les Écrivains et la Politique (Sapiro, 2018), is to have developed further the contentious concept of secular prophetic leadership. She discusses periods of widespread crisis - not least induced by war (Bourdieu, 1988, 1991, Sapiro, 2018:30) - in which prophetic figures begin to make groups, followed by new mass movements (on this, see Bourdieu, 1985: 742, Bourdieu, 2015: 579, Bourdieu, 2016: 139, 911-2, Bourdieu, 2019: 116-7). These phases of disrupted orthodoxy are illuminated by the microsociological analysis of Goffman's Frame Analysis in which he examines those moments of the "rupture of the frame", when "beliefs and commitments are turned upside- down" and "reality floats in an anomic manner" (cited Sapiro, 2018: 299).

In this 2018 book, she elucidates further Bourdieu's concept of reflexivity, distinctive to writers of the restricted field but engendered more widely by extraordinary moments of crisis. In tune with Bourdieu's later analytical use of the concept of "fragmented" or "torn habitus" ("habitus clivé" or "déchiré"), she argues that such reflexivity is intensified in those writers who possess a "habitus clivé", with its associated malaise (Bourdieu, 2000: 64, 160; 2004: 111 ${ }^{13}$; Sapiro, 2018: 67-9, 267). Mauriac - see footnote 9 - is one such figure, as is also Louis Aragon.

\footnotetext{
${ }^{12}$ These were from her sample of 185 writers. Tellingly, she concludes that they were not prosecuted for works of the imagination, such as novels, but for their pamphlets, editorials and other acts of non-fictional intervention.

${ }^{13}$ See, for example, Bourdieu on Manet's split Academic conformism and subversiveness, Bourdieu, 2013: $84-5,250,454$.
} 
Table 2 Forms of politicization in the literary field (from Sapiro, 2003b: 643)

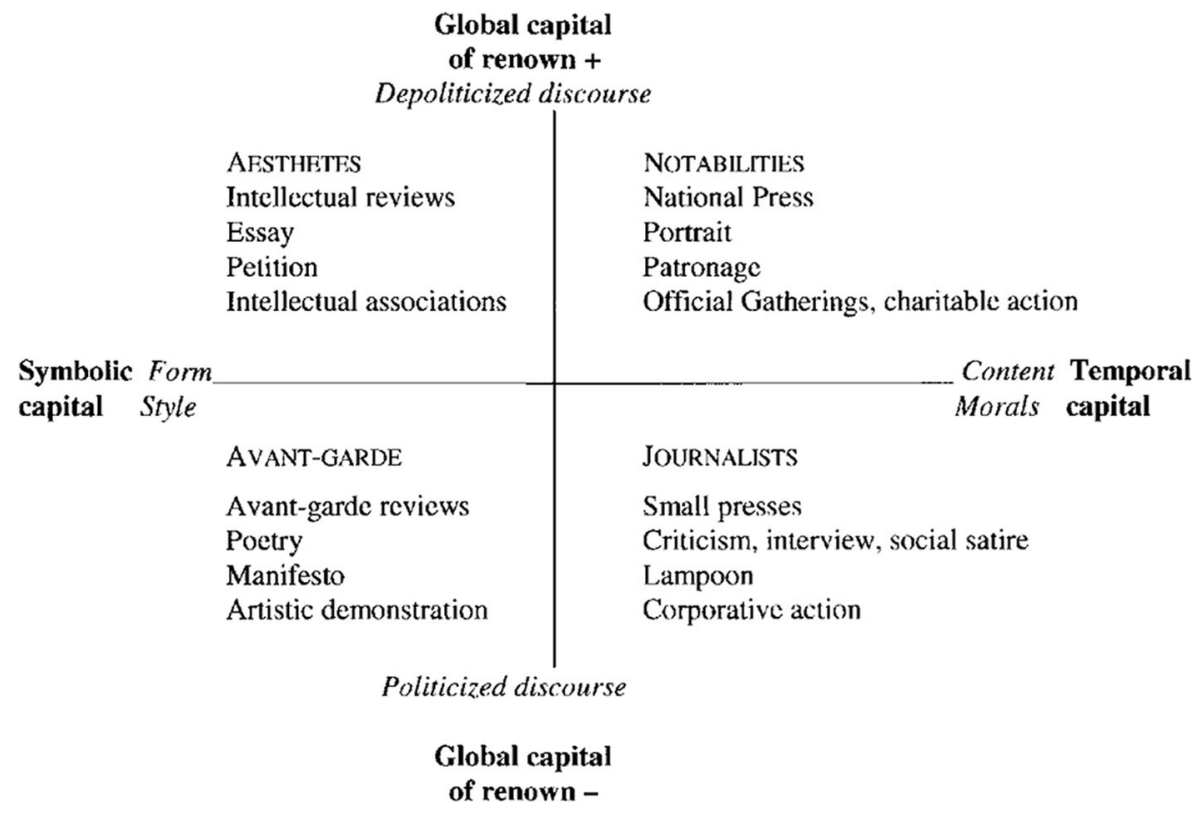

She now addresses how the late nineteenth century language of "right" and "left" in the political field was displaced in the interwar years by the pressing rupture between "fascists" and "non-fascists" (Sapiro, 2018: 40). A homologous chasm, based on literary habitus, emerged between the writers of the fascist extreme right and those opposed to them. For example, the French surrealist avant-garde became anti-fascist as a group, as witnessed by their united opposition to the French and Spanish Governments' Rif War against the Berbers (1925-1926) (2002a, Sapiro, 2009c: 22, Sapiro, 2018: 55; Lewis, 1988: 25, 33-35, 39). ${ }^{14}$ In contrast, as many as ten Académie Française writers made an imperialist appeal for "Solidarity with the Occident" (1938), legitimating Francoism (Sapiro, 2009c: 20; 31.).

As noted above, divisions within both the wider field of class power and the narrower political field were refracted and retranslated through the mediating artworlds of the literary left and right. Drawing on her earlier analysis of the conflicting literary logics of the Second World War (Sapiro, 2014a), Sapiro has now reclassified these divergent literary groups, categorising them more broadly as notables ("notabilities") (including the Académie Française category), aesthetes (including the pre-War La NRF), avant-gardes (including the CNE of 1941-1956) and journalists/polemicists (now a broader category than the Vichy Goncourt Académie alone) (Sapiro, 2003b: 643, 2018: ch. 2) (Table 2).

By 1940, as many as 44 of her original 185 writers' sample had become extreme right or fascists, the journalists/ polemicists making up by far the greatest number of

\footnotetext{
${ }^{14}$ For example, the surrealist Group of Paris (Breton, Caillois and Crevel), committed to a "reverse ethnography", contributed an excoriating critique of imperialists' "Murderous Humanitarianism" (Gopal, 2019: 312; cf. also Lewis, 1988: 95-6).
} 
these - 19 members (Sapiro, 2018: 110-11). "[C]ombining writers occupying a temporally and symbolically dominated place within the literary field" (Sapiro, 2018: 1467), they tellingly subordinated aesthetic to political judgements stemming from a deeprooted biological racism.

Further, a considerable number of fascist writers - (15)- were found amongst the notables, from the Académie Française and elsewhere, whilst there were a lesser number - (9) - amongst the aesthetes. Remarkably, there were none from the avantgarde:

[O]ne cannot speak of a Fascist 'avant-garde' in France. Nothing equivalent to Marinetti and to futurism... (Sapiro, 2018: 147].

Céline, she remarks, is the only possible candidate here. Although never a member of an avant-garde grouping, his 1932 and 1936 novels (Journey to the End of the Night and Death on the Instalment Plan) did deploy certain avant-garde traits, breaking experimentally with literary conventions by reporting the speech of the street, whilst demystifying both colonialism and militarism. ${ }^{15}$ However, Sapiro argues for his later literary "evolution" into the journalists/ polemicists' camp: disappointed by not getting the Goncourt Prize, he turned to book-length pamphlets, becoming a fascist collaborationist (Sapiro, 2018:147). Indeed, he became an irresponsible prophetic writer (Sapiro, 2018: 152), shocking even Ernst Jünger by calling for the "extermination of Jews" (Sapiro, 2018:151).

More controversially, the avant-garde writer, Aragon, represents a responsible literary prophet. An intellectual who sought a wider, popular audience for poetry (Sapiro, 2014a 336-7), it was his charismatic practices that helped to bind together the Communists and the non-Communists, as well as the dissident avant-garde groups, thus strengthening the Resistance (Sapiro, 2018: 105, 164). Aragon, she suggests, might in certain respects be compared with Manet, the epoch-making pioneer of a rupture with Academic painterly form (Bourdieu, 2013; Sapiro, 2018: 267).

Aragon's trajectory reveals the acute contradictions for poets on the anti-fascist left in the twentieth century. On the one hand, as a prophetic poet, he was indeed instrumental in renewing rhythmical form and in organizing writers to publish clandestine poetry disinterestedly, without signatures or prestige. On the other hand, especially as post-war delegate for Culture to the French Communist Party's Central Committee, he was himself subject to extraordinary political pressures. ${ }^{16}$ Publicly criticizing the Zhdanovist commissars' demands for "proletarian" or "socialist realist" conventions, Aragon used all the "margins of manoeuvre" (Sapiro, 2018: 182) that he had been bequeathed from the literary field to defend writers' independence as autonomous "specialists" in their "craft" (Sapiro, 2018: 167,198). Indeed, by sheltering

\footnotetext{
${ }^{15}$ Sapiro's argument about Celine's career does, however, raise issues over definitions, especially of the nihilist avant-garde, that require further analysis.

${ }^{16}$ For a much more critical view of Aragon's actions in relation to Soviet and East European show trials, see Judt, who compares him unfavourably with the anti-Stalinist, André Breton (Judt, 1992: 55-56, 102, 118, 218; on this Aragon/Breton conflict see Sapiro (Sapiro, 2014a:20,60, 392, 419). Aragon became a "prophetic" figure during and after the Second World War, but, unlike many others, he failed to condemn either the NaziSoviet Pact in 1938 or the Soviet repression of the Hungarian Revolution in 1956; he also published some poems openly during the Occupation (Steel, 1991:63).
} 
French writers from what Raymond Williams (1980) called the "proletarian pieties" of post-1934 Soviet revolutionary romanticism, Aragon's resolute stance might easily have cost him his life (Sapiro, 2018: 155).

Sapiro's analysis here (2018) serves to shed further light on Bourdieu's consistently critical responses to references to popular theatre and working-class literature (1993b: 4-5). For Bourdieu's suspicion of claims to the popular goes hand-in-hand with his fierce support for literary autonomy (Bourdieu, 1996a: 47-140). It may be no coincidence that the defence of autonomy in debates about proletarian realism was what at issue for Aragon and many others on the left in the late 1940s and 50s. Bourdieu, I suggest, aims to remind us of this, but at the cost of ruling out totally the possibility of any artistically-powerful popular works (Bourdieu, 2000: 185, 204). Quite rightly, Sapiro does not follow him in this latter move.

Les Écrivains et la Politique offers a subtle interpretation of the different types of fascist ethos amongst writers with divergent literary habitus. Thus she distinguishes illuminatingly between fascist polemicists (eg Lucien Rebatet), fascist notables (eg Charles Maurras) and fascist aesthetes (Henri de Montherlant) (Sapiro, 2018:152-3). Tragically, the divergent modes of adherence to fascist ideology as between these different groups - in terms of world-view and form - need to be elaborated further for the reappearance of such populism at present.

Sapiro's sociological gaze has now turned to this twenty-first century literary field, pointing to hidden structural sources of conflict. The first constraint for writers is the increased professionalisation of the political field and social sciences. From the late nineteenth to the twenty-first centuries, this has pushed writers closer to a depoliticized, Establishment-oriented literary "priesthood", divorcing them from the volatile prophetic movements (Sapiro, 2004, 2018: 36-31, Bourdieu, 2019). The second source is the reemergence in the twenty-first century of "false prophets". ${ }^{17}$ Typified earlier by leaders like Céline, Maurras or Drieu, their contemporary incarnations have become singularly influential figures.

Running counter to these fascist currents, Sapiro elucidates innovative contributions from new types of contemporary writer, amongst them more educated women authors, migrants and those with trajectories as "miraculous survivors", such as Annie Ernaux and Édouard Louis, from working-class families (Bourdieu, 1996b: 228-9). She debates the sociological significance of certain controversial writers who cast a fresh eye on areas notoriously problematic in terms of artistic treatment, such as Jonathan Littell, whose The Kindly Ones (Les Bienveillants) (2006) focuses on the Holocaust.

Sapiro's major concern here is the emergence of fashionably "neoreactionary" writers, such as Houellebecq, whose Islamophobia is homologous with the antisemitism of the interwar fascist writers (Sapiro, 2018:380). An even closer homology is the celebration by Richard Millet of the "formal perfection" of the mass murders committed by the extreme right figure, Anders Breivik, which recalls the

\footnotetext{
${ }^{17}$ Sapiro's literary application of the term "false prophet" may have been drawn from Weber's references to "counter prophets" in Ancient Judaism. His analysis of the Old Testament biblical tradition distinguishes between priests on the one hand and those ethical prophets with a mission from a transcendent, monotheistic God on the other (Weber, 1952: 267-335). Crucially, the latter's warnings of potential disaster were opposed by "counter-prophets" (Weber, 1952: 272-3), including the kingly "prophets of good fortune" (Weber, 1952: 295). Sapiro's "false prophets" thus signify those writers who collude with the powerful to perpetuate their hegemony, using their charismatic power to regressive ends.
} 
aestheticization of politics by the Nazis so deprecated by Walter Benjamin (Sapiro, 2018: 377). Equally menacingly, Maurras, Rebatet and Céline have recently been reframed by new editions ${ }^{18}$ and attractive websites. (Sapiro, 2018: 390):

[The earlier fascist writers had shown] the sombre face of these relations between literature and politics. The renewed interest in their most virulent writings, in the context of the rise of the extreme right and xenophobia [...] invites a return to the history of their engagements and their contribution to the production of competing world-views..." (Sapiro, 2018: 9).

Fascists' evaluative categories - she rightly insists - are still in the "collective unconscious" (cf Bourdieu, 1990: 56).

\section{Sapiro's The Sociology of Literature (Sapiro, 2014b)}

Bourdieu's sociology of culture has had its legacy in outstanding scholars whose work has taken further or modified Bourdieu's own conclusions, most notably Jacques Dubois, Pascale Durand, John Guillory, and Joseph Jurt. Gisèle Sapiro is particularly prominent amongst these heirs, along with the late Pascale Casanova whose unusual work, The World Republic of Letters, has been acknowledged as influential by Sapiro.

The World Republic..., taking up the early nineteenth century concept of "world literature", elaborates on Bourdieu's analyses of national canons to show how unequal are the chances for international accumulation of literary capital. Casanova shows how, up to the early twentieth century, France, especially Paris, became established as the sole literary "Greenwich Mean Time" - a national space for adjudicating which authors should be consecrated, perennially legitimated by a rhetoric of universalistic openness. ${ }^{19}$ Yet, in practice, authors writing in "small languages" - such as Finnish or Rumanian - have suffered from barriers to international recognition, even if they moved to Paris. Many have felt constrained to write in a "global language", particularly French or English, yet have still found themselves doomed to be classed as mere "regional" novelists. Laying bare Western cultural pretensions to monopolize "the universal", Casanova deploys the Marxist/Bourdieusian concept - the "imperialism of the universal" - to illuminate the often-forgotten trajectories of peripheral authors. For example, such is the history of these unequal exchanges that the Nobel literary prize has never been given to a Chinese writer resident in China itself ${ }^{20}$ (Casanova, 2004: 147-8). ${ }^{21}$

\footnotetext{
${ }^{18}$ I note, in addition, the website for the Friends of Robert Brasillach, Brasillach's Relectures (Sapiro, 2002), Rebatet's Fidélité au National-Socialisme (Sapiro, 2002) and Abel Bonnard's Political Writings (2008). The planned Gallimard republication of Céline's three antisemitic pamphlets, Bagatelles..., L'Ecole des Cadavres (1938) and Les Beaux Draps (1941) was later halted, but only after multiple protests.

${ }^{19}$ Later, other metropolitan "banks of symbolic credit" emerged too, notably London and New York.

${ }^{20}$ Post-Casanova, Mo Yan won this in 2012.

${ }^{21}$ Note that the fragile conquest of literary autonomy analysed by Bourdieu (1996a) and Sapiro (2011) is now imperilled by heteronomous market pressures even in the dominant regions. Given the recent "revolution in publishing" (Bourdieu, 2008b) each new literary title must make 12-15\% profit (Casanova, 2004: 170; cf. Bourdieu 2008, Sapiro, 2014b: 42-43, Schiffrin, 2000: 105-6, 109), Thompson, 2010).
} 
It is within this wider, Bourdieu-initiated, research programme that we should evaluate Sapiro's contribution. Crucially, Sapiro follows in Bourdieu's footsteps by breaking both with internalist approaches - works interpreted in terms solely of a narrow literary tradition - and also solely externalist approaches: the reduction of literary works to class world visions within a given mode of production (cf Bourdieu, 1993: 56, 2013: 82-3). Instead, she amply encompasses internal subversion of literary form, wider external structural determinants and the development of writers' literary habitus. Introducing, in this way, the mediating institutions of the literary field (circles, anthologists, critics, publishers, Nobel judges, etc.), as we have seen, she is perhaps more sensitive to historical variations than Bourdieu (see Sapiro 2019). Most crucially, she shows that demands for literary autonomy are not necessarily asserted via a formalist aesthetic - revolving round art for art's sake - as Bourdieu claimed. Rather, she agrees with Jurt that a national-popular movement has often led authors to produce path-breaking literary works within a peripheral "counter-field", which have become consecrated later (Jurt, 2009: 214-5). This has been important, for example, in the margins of the Francophone space (Belgium, Quebec, and French-speaking Switzerland) (Dubois, 1978: 123-137, Fowler, 2017, Jurt, 2001: 97-99, 2009: 213-222, Sapiro, 2014b:72-9).

Sapiro is also more aware of literary space as an arena for masculine domination than was Bourdieu. Bourdieu had referred to women outsiders - such as Virginia Woolf - possessing a "lucid vision" (Bourdieu, 2001: 81, 109). Yet he never developed his detailed phenomenology of the literary field to address women writers as a group, a silence rectified by Sapiro (2007; 2014b: 44-45, 61). Further, despite Bourdieu's penetrating dialogue about oral poetry with the Algerian poet, Mahmoud Mammeri, it has been left to Sapiro, Casanova and other sociologists to advance a Bourdieusian analysis of the postcolonial literary field (Bourdieu, 2008a: 125, 137, 291, 299, 305, 2016: 139; Sapiro, 2014b; see also Dalleo, 2016).

Sapiro's assessments of this subfield to date have certain lacunae. For example, the advances pioneered by Neil Lazarus (2004) and Andrew Smith (2004) are omitted as well as the Frederic Jameson (1986)/ Aijaz Ahmad (1992) debate. However, she and her former doctoral student, Claire Ducournau, have begun valuable work in addressing postcolonial literature emerging from Francophone Subsaharan Africa (Sapiro, 2014b: 76-77, 2018: 384-5).

In sum, Sapiro writes strikingly of the higher "entry costs" for writers from such peripheral regions and other subaltern groups:

The conditions of access to this [contemporary literary] universe are actually very socially selective: white men, born in, or having moved to, Paris in their adolescence, coming from privileged social origins and acquiring a more advanced level of education, have more chances of becoming recognised than women, black or mixed-race writers, provincials, the children from the subordinate classes and those who do not possess the bac (Sapiro, 2014b: 72).

Sapiro's impressive body of work has major implications. We have noted as one such her deployment of Max Weber's conceptual oppositions of priest and prophets, ethics 
of responsibility and ethics of conviction. ${ }^{22}$ For Weber, Bourdieu and Sapiro, the authentic prophet has the lonely voice of one "rejected of men" who rises to the fore at a time of crisis (see Sapiro, 2014a). Their once-derided warnings of bad fortune chime at such junctures with the current public's turbulent experience, making sense of their confusion and despair. As Bourdieu adds, the prophet's own sufferings, not least within the religious field, authorise them to speak for the masses. They have founded new principles of vision and division that help to consolidate into a unified subordinate class those closest to material urgencies within the economy - the precarious, the dispossessed, and the "left behinds" (Bourdieu, 1987, 2016: 139, 1073). In other words, through his characterisation of the prophetic role and the prophet's transfer of cultural capital to the masses, Bourdieu begins to elucidate a theory of change, even revolution (Bourdieu, 2000:188 cf. also Bourdieu, 1996b:387-9). Sapiro's importance lies more in addressing political rather than economic crises: her work on the French World War II writers, in particular, has shown how the different structural histories of each field were affected by a forced "phase harmonisation" (Sapiro, 2013: 266). The "restructured" literary field, in particular, witnessed a loss of autonomy but it also saw the birth of new literary generations and new prophets. As she quotes from Bourdieu (1971): "The prophet is the man of crisis situations, where the established order topples over and the future is suspended." (cited Sapiro, 2014a: 178).

\section{The prophetic writers' interests in disinterestedness: Sapiro vis-à-vis Bourdieu}

Pierre Bourdieu's The Love of Art, Distinction and The Field of Cultural Production have been powerfully demystifying: by revealing the perspectival nature of cultural reception - especially linking taste to social groups' material and educational experience - his scientific gaze has further disenchanted the world. He shocked even more by revealing the interests behind apparent disinterestedness, not least with respect to Zola. Thus on the one hand, he describes Zola's "prophetic denunciation", "J'accuse...!" (1898) as "exemplary" (Bourdieu, 1993:63). On the other hand, Zola's "prophetic subversion" enabled him to achieve specific literary interests: his "mission" could compensate for the "vulgarity" of his popular novels, permitting symbolic long-term profits (Bourdieu, 1993: 54 ,1996a: 116, 128-9).

In Practical Reason Bourdieu counselled helpfully against a "crude" interpretation of writers' practices as consciously calculative, a view based on a hasty reading of Distinction (Bourdieu, 1998: 90). Instead, he argues that for those with a literary habitus the game of literature is one where the stakes become so high that they become a matter of "passion", or even life and death. It is this "infraconscious" "illusio", not

\footnotetext{
${ }^{22}$ At first sight it might seem that she does not seek to distinguish between the ethics of responsibility and conviction, as does Weber (1948: 118-128). However, a closer reading shows that for her, it is the conservative writers of the nineteenth century who espouse an ethic of responsibility whereas Zola defends an ethic of conviction. Later, a writer such as Sartre expands his ethic of responsibility to embrace also a universalistic ethic of conviction. The fact that he did not always live up to this ethic - remaining silent, for example, at the time of the Stalinist show trials in Hungary (1949) and Czechoslovakia (Weber, 1952) (cf Judt, 1992:186) - does not negate the significance of this stance.
} 
utilitarian interests, that led André Breton to break a rival surrealist's arm in a poetic battle (Bourdieu, 1998:88).

Sapiro has deepened Bourdieu's perspectivist arguments in a number of works. But she has also elaborated further on the reflexive capacities of the writer and her distinctive analysis of Zola's political intervention exhibits certain significant differences from his. She makes no reference to Zola being anxious to accumulate symbolic profits so as to counteract the perceived aesthetic problem posed by his bestselling novels. Rather, Sapiro's independent research provides ample evidence for his belief in his novels. More precisely, given the critical opprobrium heaped on him, Zola defended himself in terms of a literary experimental ethic - an ethic engendered by a fearless naturalist gaze as well as by his concern for social justice. Thus, attacked first for his foreign surname and later for his stirring defence of Dreyfus, he emphasizes both his French nationality and "the glory to the nation" brought by the international sales of his books.

Moreover, as Sapiro documents, "J'accuse!" is not a singular late intervention ensuring literary redemption. For Zola had earlier undertaken the courageous act of publishing The Republic and Literature (1979), in which he asks whether the contemporary Republic will be the friend or foe of those writers - "collectors of human documents" - who rely on "the authority of fact":

For me, the existence of the Republic herself depends on it. The Republic will live or it will not live according to whether it will accept or reject our method. The Republic will be naturalist or it will not be. (Zola 20 April 1879, cited Sapiro 378-9).

Six years later, Zola's Germinal (1885) contained as its underlying theme the impending internecine struggle between capital and labour, unpalatable to the industrial bourgeoisie (Sapiro, 2011: 505). This might be said to represent nothing less than the (ethical) "prophecy of bad fortune" in our terms.

Interestingly also, for Sapiro, Zola's "experimental novel" with its scientific paradigm shares certain innovative elements with those in the consecrated literary field. He "systematized" the indirect free discourse pioneered by Flaubert:

The narrator effaces himself behind his characters in order to adopt their perspective, allowing their way of seeing the world to be seen ... (Sapiro, 2011: p 400)

Sapiro's powerful sociological analysis of Zola places more emphasis than does Bourdieu on his disinterested political concerns and literary inventiveness, less on the aesthetic profits supposedly pursued via this strategy. Indeed, in this respect she has been forceful in developing further Bourdieu's own call for intellectuals to maintain a "corporatism of the universal" (Bourdieu, 1989).

One final point. Sapiro's succinct but masterly overview, The Sociology of Literature (Sapiro, 2014b), draws explicitly on the analogy between the writer and the prophet, elucidating in these terms even the clashes between avant-gardes. Her example is the 1870s Parnassian group led by a "prophetic" innovator, Leconte de Lisle, who made a "symbolic revolution" by bringing about an extraordinary change in literary language. Yet, over time, this poetic revolution became consecrated and routinised, doomed to be 
overtaken by a "new heresy", that represented by the poetry of Verlaine and Mallarmé (Sapiro, 2014b:71). She casts this dialectic as a "permanent revolution". 23

Now, Sapiro has herself noted that, during the crisis of the Second World War, this did not happen: the three surrealist generations bonded together to oppose the Vichy Government and German occupation. This being so, I would argue that the dialectic of successive heresies, group-consecration and routinisation in her Sociology of Literature risks being too mechanistically "internalist" an analysis, the literary field too divorced from other fields.

Sapiro's argument here - following that of Bourdieu - is derived from the French field. But, as Bourdieu himself recognised, its degree of generality remains to be assessed (Bourdieu, 1998: 2-6, 13, Jurt, 2001: 93-94, 94, fn23). Whilst certain "essential" relational similarities exist elsewhere, particular historical differences also emerge (Bourdieu, 1998:13). We should ask: do all avant-gardes become consecrated quickly, routinized and contained within the cultural field, as Bourdieu and Sapiro seem to suggest? Might specific avant-garde movements remain insulated and cut off from the world rather than risking routinisation within it? Alternatively, might certain avantgardes possess literary forms so powerful that they manage to endure by expressing their discontents; indeed, manage not just to voice their own indignation and suffering, but that of uneducated men and women more widely? This was the case, for example, with the African-American Harlem Renaissance's (1917-1938) avant-garde writings (notably, Claude McKay, Zora Neale Hurston, Langston Hughes, Anne Spencer, Alain Locke, Nella Larsen and James Weldon Johnson). Many of these writers adopted a strategy of "symbolic alchemy": taking the distinctive experiences and everyday idioms of a group whose speech was not normally represented in literature, they turned it into "literary gold". ${ }^{24}$ Often denied consecration, most stayed close to their original subjects and readership, rather than moving into a more exclusively literary world.

To answer questions such as these about the dialectic of consecration and routinisation further research is needed. In my view, this cannot be restricted to analysing competing avant-gardes alone but needs also to address writers in surrounding fields. Figures such as W.E. B. Du Bois, in 1920s' American sociology, possessed the ability to amplify the discontents voiced in this Harlem Renaissance writing, delaying its banalising routinisation.

In brief, despite Sapiro's very valuable analysis of specific societal crises - France in the Dreyfus Affair and after the 1940 defeat (Sapiro, 2013, 2014a, 2018: 99) numerous questions remain outstanding. Even with her later research on Aragon and the surrealists, she has not yet undertaken a more general comparative analysis of the preconditions for autonomous avant-gardes breaking out influentially, going beyond what Bürger has called the "sacred island" reserved in late modernity for art and literature (cf Bürger, 1984). For - as she has shown re World War II - I would argue that at certain key historical points, the power of literature to articulate movements for social and political change has been very marked, as in the case of James Joyce's Portrait of the Artist as a Young Man, Ignazio Silone's Fontamara, Toni Morrison's Beloved or Ngûgï wa Thiong'o's Petals of Blood.

\footnotetext{
${ }^{23}$ This term initially described the continuous historical movement from a bourgeois to a socialist revolution: in the modernist literary field no such analogy can be made.

${ }^{24}$ See for example Z.N.Hurston's Their Eyes were Watching God, Virago 2020 [1937]. The notion of "literary gold" comes from Casanova (2004:334).
} 


\section{Conclusion}

The final words of Sapiro's, 2011 work clarify the ethic of the writer within the contemporary public sphere:

[I]t is not without importance at a time when storytelling becomes a technique of communication and of power which invades every social domain [...] to praise not simply the cognitive but the ethical virtues of the reflexive work undertaken by novelists on narrative forms [...]. Autonomy in relation to morality or the dominant ideology is always the condition of this problematising of our schemes of perception, action and evaluation of the world which, without [the author], would continue to go unquestioned. Therein lies the responsibility of the writer (Sapiro, 2011: 720, my emphasis).

This "deontological" or occupational ethic and its characteristic reflexivity might be seen as merely a reiteration of Sartre's "littérature engagée" or his "total" intellectual (Sapiro, 2009c: 16-17, cf. Baert, 2015). However, Sapiro has argued for other resources: notably Durkheim's neglected arguments at the height of the Dreyfus Affair (Sapiro, 2009c:17, Durkheim, 1969[1898]). Here Durkheim emphasizes that intellectuals' persuasive power derives from their occupational obligation to place "reason above authority" and to defend their conclusions publicly even in the face of opposition. Such interventions are based on specific areas of expertise (Durkheim 1969: 24, Bourdieu, 2004). It is from Durkheim, and later Michel Foucault, that Bourdieu emphasized his conception of the sociologist, qua specific intellectual, who supplies information based on their accumulated competencies to workers or other oppressed groups (Sapiro, 2009c: 30). Sapiro, similarly, links the reasoned defence of an ethico-political position, coupled with an aesthetic stance, to the critical-humanist writer, as in the "nouveau roman" signatories to the Manifesto of the 121 in the Algerian war (Sapiro, 2009c:22, 31, 2018:365).

Sapiro has reminded us once again of the pressing importance of literature today, in terms of ideology and reflexivity. Her analysis of French writers' intellectual trajectories and of their literary responsibility has rightly become extended to combine the most subtle theorists of the Marxist lineage, such as Lucien Goldmann (Sapiro, 2018: 212), with the sociological theory of transformation offered by Pierre Bourdieu. Whilst differentiating her approach from Bourdieu on issues of popular literature, on interests in disinterestedness and on wider concerns with postcolonial writing, she has remained within the symbolic revolution initiated by Bourdieu himself. Put succinctly, her contribution to the sociology of literature has been both historically rich and theoretically challenging, bringing together new empirical studies under a well-supported conceptual panoply.

Supplementary Information The online version contains supplementary material available at https://doi.org/ 10.1007/s11186-021-09445-1.

Acknowledgments The author would like to express great gratitude to Esperança Bielsa, Seán Damer, Vassiliki Kolocotroni and Andrew Smith, together with the Theory and Society editors and peer reviewers, for assistance in revising this article.

Code availability Not applicable. 


\section{Declarations}

Conflict of interest Not applicable.

Ethics approval Not applicable.

Consent to participate Not applicable;

Consent to publish Not applicable.

Open Access This article is licensed under a Creative Commons Attribution 4.0 International License, which permits use, sharing, adaptation, distribution and reproduction in any medium or format, as long as you give appropriate credit to the original author(s) and the source, provide a link to the Creative Commons licence, and indicate if changes were made. The images or other third party material in this article are included in the article's Creative Commons licence, unless indicated otherwise in a credit line to the material. If material is not included in the article's Creative Commons licence and your intended use is not permitted by statutory regulation or exceeds the permitted use, you will need to obtain permission directly from the copyright holder. To view a copy of this licence, visit http://creativecommons.org/licenses/by/4.0/.

\section{References}

\section{(Actes de la Recherche en Sciences Sociales appear beneath as Actes...)}

Ahmad, A. (1992). In Theory: Classes, Nations, Literatures. Verso.

Baert, P. (2015). The Existentialist Moment: The Rise of Sartre as a Public Intellectual. Polity.

Ben-Amos, A. (2000). Funerals, Politics and Memory in Modern France (1989-1996). Oxford University Press.

Bielsa, E. (2014). Cosmopolitanism as Tanslation. Cultural Sociology, 8(4), 392-406.

Bielsa, E. (2016). Cosmopolitanism and Translation. Routledge.

Bourdieu, P. (1971). Genèse et structure du champ religieux. Revue française de sociologie, 12 (no 3 ) 331.

Bourdieu, P. (1980). Sartre, London Review of Books, Vol 2, 20 Nov. to 3 Dec.: 11-12.

Bourdieu, P. (1984). Distinction. RKP.

Bourdieu, P. (1985 [1984]). Social Space and the Genesis of Groups. Theory and Society, 14(6), 723-744.

Bourdieu, P. (1987 [1971]). Legitimation and Structured Interest in Weber's Sociology of Religion. In S. Lash \& S. Whimster (Eds.), Max Weber, Rationality and Modernity (pp. 119-136). Allen and Unwin.

Bourdieu, P. (1988). Homo Academicus. Polity.

Bourdieu, P. (1989). The Corporatism of the Universal. Telos, 81(Fall), 99-110.

Bourdieu, P. (1990). The Logic of Practice. Polity.

Bourdieu, P. (1991). The Political Ontology of Martin Heidegger. Polity.

Bourdieu, P. (1993). The Field of Cultural Production. Polity.

Bourdieu, P. (1996a). The Rules of Art. Polity.

Bourdieu, P. (1996b). The State Nobility. Polity.

Bourdieu, P. (1998). Practical Reason. Polity.

Bourdieu, P. (2000). Pascalian Meditations. Polity.

Bourdieu, P. (2001). Masculine Domination. Polity.

Bourdieu, P. (2004). Science of Science and Reflexivity. Polity.

Bourdieu, P. (2008a) Esquisses Algériennes. T. Yacine (Ed.). Seuil.

Bourdieu, P. (2008b). A Conservative Revolution in Publishing. Translation Studies, 1(2), 123-153.

Bourdieu, P. (2013). Manet: Une Révolution Symbolique. Raisons d'Agir, Seuil.

Bourdieu, P. (2015). Sociologie Générale (Vol 1). Raisons d'Agir, Seuil.

Bourdieu, P. (2016). Sociologie Générale (Vol. II). Raisons d'Agir, Seuil.

Bourdieu, P. (2019). Classification Struggles: General Sociology (Vol. 1). Polity.

Bourdieu, P., \& Passeron, J. C. (1990). Reproduction in Education, Society and Culture. Sage. 
Bourdieu, P., \& Wacquant, L. J. D. (1992). Invitation to a Reflexive Sociology. Polity.

Bürger, P. (1984). Theory of the Avant-Garde. Manchester University Press.

Casanova, P. (2004). The World Republic of Letters. Harvard University Press.

Clifford, J. (1981). On Ethnographic Surrealism. Comparative Studies in Society and History, 23 (4) Oct.: 539-564.

Dalleo, R. (Ed.). (2016). Bourdieu and Postcolonial Studies. Liverpool University Press.

Deutscher, I. (1954). The Prophet Armed. Oxford University Press.

Dubois, J. (1978). L'Institution de la Littérature : Introduction à une Sociologie. Editions Labor, Fernand Nathan.

Durkheim, E. (1969 [1898]). Individualism and the Intellectuals (pp. 19-30) In S. Lukes (1969). (Ed) Durkheim's Individualism and the Intellectuals. Political Studies, 17(1), 14-30

Fowler, B. (1991) The Alienated Reader. Harvester Wheatsheaf.

Fowler, B. (2007) The Obituary as Collective Memory. Routledge.

Fowler, B. (2017) Pierre Bourdieu: State, Enlightenment and the Scottish Literary Field, pp 71-90 in eds. L. Adkins, C. Brosnan and S. Threadgold et al, Bourdieusian Prospects. Routledge.

Fowler, B. (2020) Pierre Bourdieu on Social Transformation with Particular Reference to Political and Symbolic Revolutions, Theory and Society, 49(3), 439-463.

Goldmann, L. (1964). The hidden God. Routledge and Kegan Paul.

Gopal, P. (2019). Insurgent Empire. Verso.

Guillory, J. (1993) Cultural Capital. University of Chicago Press.

Hall, S. (1980). Encoding/decoding (pp. 128-138). In S. Hall et al. (Eds.) Culture, Media, Language: Hutchinson.

Jameson, F. (1986). Third-world Literature in the Era of Multinational Capitalism. (Autumn), 65-88.

Lazarus, N. (2004). Introducing Postcolonial Studies. In N. Lazarus (Ed.), The Cambridge Companion to Postcolonial Literary Studies (pp. 1-16). Cambridge University Press.

Lewis, H. (1988). Dada Turns Red: The Politics of Surrealism. Edinburgh University Press.

Judt, T. (1992). Past Imperfect: French Intellectuals, 1944-56. University of California Press.

Jurt, J. (2001). Autonomy and Commitment in the French Literary Field. International Journal of Contemporary Sociology, 38(1), 87-102.

Jurt, J. (2009). Le Champ Littéraire entre le National et le Transnational. In G. Sapiro (Ed.) L'espace intellectuel en Europe (pp 201-232). La Découverte.

Mauriac, F. (1947 [1943]) [Forez]. Le Cahier Noir. Editions de Minuit.

Muel-Dreyfus, F. (2001 [1996]). Vichy and the Eternal Feminine. Duke University Press.

Sapiro, G. (2002). La Responsabilité de l'Ecrivain: de Paul Bourget à Jean-Paul Sartre. In M. Einfalt \& J. Jurt (Eds.), Le Texte et la Contexte: Analyse du champ littéraire française (pp. 219-240). Maison des Sciences de l'Homme.

Sapiro, G. (2003a). The Literary Field Between the State and the Market. Poetics, 31(5-6), 441-464.

Sapiro, G. (2003b). Forms of Politicization in the French Literary Field. Theory and Society, 32, 633-652.

Sapiro, G. (2004). Le savant et le littéraire: Les hommes de lettres contre la sociologie durkheimienne. In J. Heilbron, R. Lenoir, \& G. Sapiro (Eds.), Pour une histoire des sciences sociales (pp. 83-106). Fayard.

Sapiro, G. (2007). « Je n'ai jamais appris à écrire » : les conditions de formation de la vocation de l'écrivain. Actes...168(3): 12-33.

Sapiro, G. (2008). Translation and the Field of Publishing: a commentary of Pierre Bourdieu's "A Conservative Revolution in Publishing". Translation Studies, 1(2), 154-166.

Sapiro, G. (2009a). L'internationalisation des champs intellectuels dans l' entre-deux-guerres: facteurs professionels et politiques. In G. Sapiro (Ed.), L'Espace Intellectuel en Europe (pp. 111-146). La Découverte.

Sapiro, G. (2009b). L'Europe, Centre du Marché mondial de la Traduction. In G. Sapiro (Ed.), L'Espace Intellectuel en Europe (pp. 249-297). La Découverte.

Sapiro, G. (2009c). Modèles d'intervention politique des intellectuels : Le cas français. Actes ...., 176-7(1), 831.

Sapiro, G. (2010). Globalisation and Cultural Diversity in the Book Market: The Case of Literary Translations in the U.S. and in France. Poetics, 38, 419-439.

Sapiro, G. (2011). La Responsabilité de l'Écrivain: Littérature, Droit et Morale en France (XIX - XXI siècle). Seuil.

Sapiro, G. (2013). Structural History and Crisis Analysis: The Literary Field in France in the Second World War. In P.S. Gorski, Ed., Bourdieu and historical analysis (pp. 266-285). Duke University Press.

Sapiro, G. (2014a [1999). The French Writers' War: 1940-1953. Duke University Press.

Sapiro, G. (2014b). La Sociologie de la Littérature. La Découverte. 
Sapiro, G. (2015). Translation and Symbolic Capital in the Era of Globalization: French Literature in the US. Cultural Sociology, 9(3), 320-346.

Sapiro, G. (2018). Les Écrivains et la Politique en France. Seuil.

Sapiro, G. (2019). The Writing Profession in France. French Cultural Studies, 30(2), 105-120.

Sapiro, G., \& Heilbron, J. (2007). Outline for a Sociology of Translation. In M. Wolf \& K. Fukari (Eds.), Constructing a Sociology of Translation (pp. 93-107). John Benjamins.

Sartre, J.-P. (1967 [1950]). What is Literature? Methuen.

Sayer, A. (1999). Bourdieu, Smith and Disinterested Judgement. The Sociological Review, 47(3), $403-431$.

Schiller, F. (1994). On the Aesthetic Education of Man. Thoemmes Press.

Simmel, G. (1955). Conflict and the Web of Group-affiliations. Glencoe Free Press.

Schiffrin, A. (2000). The Business of Books. Verso.

Smith, A. (2004). Migrancy, Hybridity and Postcolonial Literary Studies. In N. Lazarus (Ed.), The Cambridge Companion to Postcolonial Literary Studies (pp. 241-261). Cambridge University Press.

Steel, J. (1991). Littératures de l'Ombre. Presses de la Fondation National des Sciences Politiques.

Thompson, J. (2010). Merchants of Culture. Polity.

Weber, M. (1948 [1919]). Politics as a Vocation; Religious Rejections of the World and Their Direction. In H. Gerth and C.W. Mills (Eds.), From Max Weber (pp. 77-128 and pp. 323-359). Routledge and Kegan Paul. Weber, M. (1952). Ancient Judaism. Free Press.

Weber, M. (1978). Economy and Society. (G. Roth and K. Wittich (Eds.)), University of California Press.

Weber, M. (1995). The Russian Revolutions. Polity.

Weber, M. (2012 [1919]). Science as a Profession and Vocation. In H. H. Bruun \& S. Whimster (Eds.), Max Weber: Collected Methodological Writings (pp. 335-353). Routledge.

Williams, R. (1980). Problems in Materialism and Culture. Verso.

Online source: Wikipedia: https://fr.wikipedia.org/wiki/Régime_de_Vichy\#Les_Juifs_en_France_de_ 1940_à_mi-1942 (Accessed February 26th 2021).

Publisher's note Springer Nature remains neutral with regard to jurisdictional claims in published maps and institutional affiliations.

Bridget Fowler is an Emeritus Professor of Sociology (Glasgow). She is particularly interested in social theory, Marxist-feminism and the sociology of culture. Her publications include - amongst others - The Alienated Reader (1991); Pierre Bourdieu and Cultural Theory (1997); The Obituary as Collective Memory (2007); and Pierre Bourdieu: Unorthodox Marxist? in ed. S. Susen and B.S.Turner, The Legacy of Pierre Bourdieu (2011). Her most recent work is Pierre Bourdieu on Social Transformation with particular reference to political and symbolic revolutions, Theory and Society (2020) 49 (3), 439-463. https://doi.org/10.1007/ s11186-019-09375-z. 